\title{
Article \\ Performance Management and the Police Response to Women in India
}

\author{
Monica Kapuria ${ }^{1}\left(\mathbb{1}\right.$ and Edward R. Maguire ${ }^{2, *}$ (D) \\ 1 School of Management, Babu Banarasi Das University, Lucknow 226028, Uttar Pradesh, India; \\ monicakapuria@bbdu.ac.in \\ 2 School of Criminology and Criminal Justice, Arizona State University, Phoenix, AZ 85004, USA \\ * Correspondence: edmaguire@asu.edu
}

Citation: Kapuria, Monica, and Edward R. Maguire. 2022.

Performance Management and the

Police Response to Women in India

Social Sciences 11: 58. https://

doi.org/10.3390/socsci11020058

Academic Editor: Nigel Parton

Received: 10 December 2021

Accepted: 28 January 2022

Published: 7 February 2022

Publisher's Note: MDPI stays neutral with regard to jurisdictional claims in published maps and institutional affiliations.

Copyright: (c) 2022 by the authors. Licensee MDPI, Basel, Switzerland. This article is an open access article distributed under the terms and conditions of the Creative Commons Attribution (CC BY) license (https:// creativecommons.org/licenses/by/ $4.0 /)$.

\begin{abstract}
Crimes against women have critical implications, not only for victims but also for overall community health and safety. Communities entrust law enforcement agencies with the responsibility to safeguard vulnerable people through effective and efficient policing approaches that provide a safe environment. Enhancing and improving the efficiency and performance of the police is an important part of preventing and reducing crimes against women. One approach to addressing specific performance targets is to adopt a performance management strategy. This paper examines survey data from 310 police officials in northern India about one such strategy: the balanced scorecard (BSC). Our analysis illuminates police perspectives about the perceived benefits of a generalized performance management strategy such as the BSC for improving police performance in addressing crimes against women and the needs of female citizens. Our findings reveal that respondents' assessments of all four dimensions of the balanced scorecard are associated with their degree of optimism that performance measurement can improve the police response to crimes against women.
\end{abstract}

Keywords: police; crimes against women; performance management; balanced scorecard; India

\section{Introduction}

Governments authorize police to enforce the law and preserve public safety and public order in communities. Yet, police officials are typically given wide latitude about how to achieve these broad mandates. Moreover, individual police agencies are often situated in very different environments with different workload challenges (Langworthy 1986; Maguire 2003). As a result, there are significant differences in organizational structure, behavior, and performance across agencies. Developing a comprehensive suite of performance measures is often viewed as an important step in improving police performance (Maguire 2004, 2005; Moore 2002, 2003). Ideally, police performance should be evaluated using multiple dimensions and multiple indicators intended to tap into a wide range of police responsibilities (Gallagher et al. 2001; Neyroud 2008; Sparrow 2015). One such responsibility is preventing crimes against women and responding appropriately and compassionately to the needs of female citizens. Unfortunately, very little research has focused on measuring these elements of police performance (Rollings and Taylor 2008).

Crimes against women are considered one of the most important social problems in many nations (DeKeseredy and Schwartz 2011; Michau et al. 2015; Simons and Morgan 2018). One key aspect of addressing this problem is optimizing the nature and manner of the police response, ensuring that it is efficient, effective, and compassionate (Maddox et al. 2011; Stanko 2007). Given the gravity of this issue, one useful approach may be to develop an effective performance management framework for police agencies that helps to improve their handling of crimes against women. Ideally, such a framework would consider both prevention and response. Put differently, a multidimensional framework for optimizing the police handling of crimes against women should seek to prevent these offenses in the first place and to respond appropriately when such offenses occur. However, little is known 
about the extent to which generalized performance management frameworks can influence the police response to specific issues such as crimes against women.

Though there is now a large body of research on crimes against women globally, most of the research evidence on police performance with regard to crimes against women comes from developed nations, particularly the United States, the United Kingdom, and Australia. Much less is known about the police handling of crimes against women in the developing world. This study draws on data from a survey of police officials in the state of Uttar Pradesh in northern India to provide insights about police performance management and crimes against women in an environment where these issues are highly salient and much remains to be learnt. Research reveals that crimes against women are a serious and highly prevalent issue in India (Mangoli and Tarase 2009; Mukherjee et al. 2001; Singh 2016). Some scholars argue that women in India continue to be victimized "due to deeply seated social prejudices that make them vulnerable to violence and discrimination" (Himabindu et al. 2014, p. 1).

Addressing a public safety issue such as crimes against women that is so embedded in a nation's culture and social structure is likely to be challenging. Although the criminal justice system alone cannot solve the problem of crimes against women, a significant body of research evidence suggests that criminal justice reform, including police reform, can play an important role (Sherman et al. 1992; Spohn and Tellis 2015). Here, we examine police perceptions of one type of reform: a generalized performance management system that is intended to improve police effectiveness, efficiency, perceived legitimacy, and other key outcomes. Police in several countries have tested and adopted a balanced scorecard (BSC) approach to performance management. The BSC is a strategic performance management tool developed for private sector companies but later adapted for use in other settings, including nongovernmental organizations and public agencies (Greatbanks and Tapp 2007; Northcott and Taulapapa 2012). The BSC examines four dimensions of an organization's performance: finances, customers, internal processes, and learning and growth (Kaplan and Norton 1992). This paper examines the relationship between officers' ratings of the importance of these individual dimensions and the perceived benefits of performance management for improving the police response to crimes against women and the needs of female citizens.

\section{Literature Review}

This review of the literature is divided into three subsections. The first provides a brief review of the literature on crimes against women, both in general and in India specifically. The second provides a brief review of the literature on performance management strategies in policing, with a specific focus on the balanced scorecard approach. The third reviews what little is known about the use of performance management strategies to improve the police response to crimes against women.

\subsection{Crimes against Women}

Crimes against women are a major social problem worldwide. The World Health Organization (2013, p. 3) refers to violence against women as "a global public health problem of epidemic proportions". Most such crimes are carried out by male offenders against female victims. These offenses are often characterized by "coercive control that is maintained by tactics such as physical violence, psychological abuse, sexual violence, and denial of resources" (Crowell and Burgess 1996, p. 10). The consequences of these offenses are far-reaching and, in some cases, intergenerational (McFarlane et al. 2014; Schwerdtfeger and Goff 2007). Research has shown that victims suffer a host of serious physical and psychological consequences and often experience ongoing trauma, including post-traumatic stress syndrome and other deleterious mental health outcomes (Pico-Alfonso et al. 2006; Stein and Kennedy 2001; Zoellner et al. 2000).

While crimes against women occur in all countries, cultural and structural factors render these problems much more acute in certain developing nations (Haugen and Boutros 
2014; Heise et al. 1994). Crimes against women are especially salient in India, a patriarchal society where "deep-rooted prejudicial attitudes towards women and other deeper societal issues" create an environment in which crimes against women are often not taken seriously (Himabindu et al. 2014, p. 5). Indeed, India ranked 122nd out of 189 nations on the United Nations Development Programme's (2018) Gender Inequality Index (put differently, nearly two-thirds of nations have greater gender equality than India). Figure 1 shows the rates of serious crimes against women (per 100,000 population) for India as a whole and for Uttar Pradesh, the state where our research took place. While the rate of reported crimes against women has mostly trended downward nationally in India from 2012 to 2019, the rate has trended upward in Uttar Pradesh. Research has documented high levels of gender inequality in Uttar Pradesh, including significant disparities in education, economic status, health, and criminal victimization (e.g., Ahmad et al. 2016; Hebert et al. 2020; Mogford 2011; Mohan and Yadav 2019; Silverman et al. 2019; Sudha and Morrison 2011).

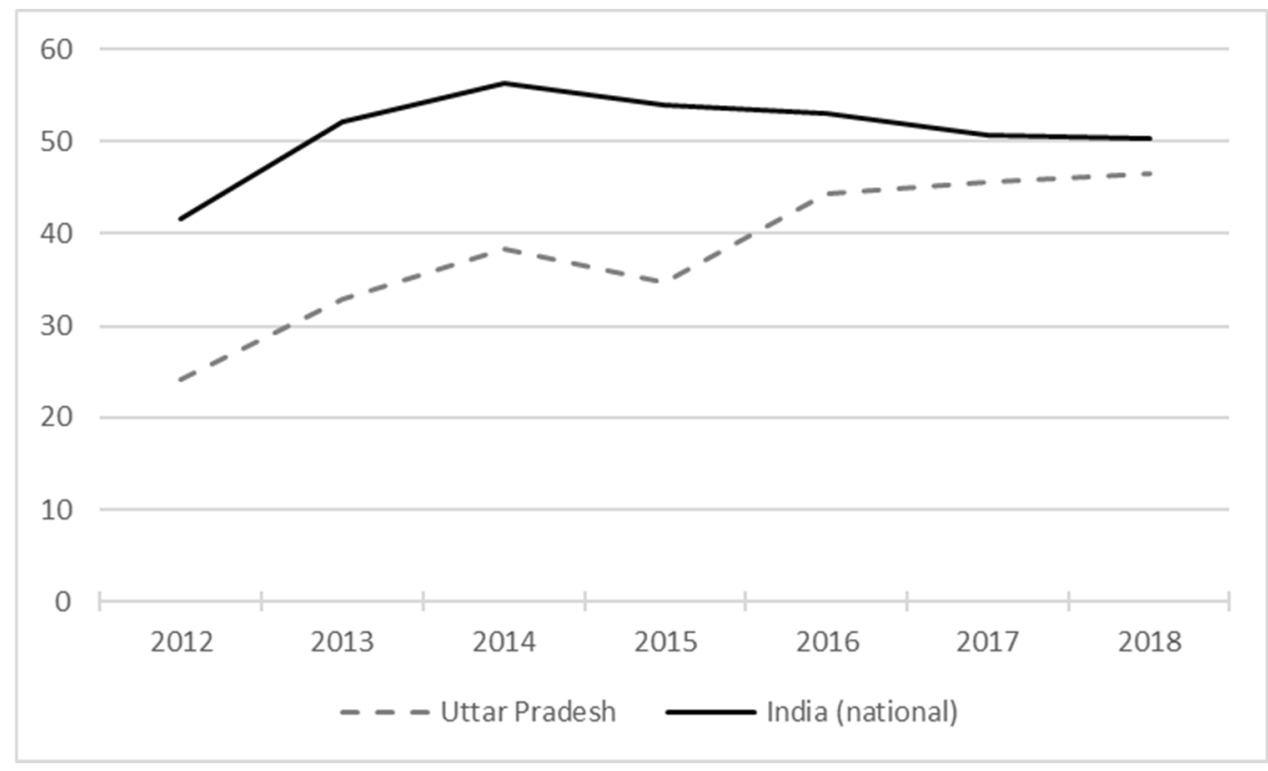

Figure 1. Rate (per 100,000) of serious crimes against women, 2012-2019. Note: Serious crimes are defined here as those recorded under the Indian Penal Code (IPC) and not those recorded under special and local laws (SLL) (National Crime Records Bureau 2019).

Many institutional sectors can play an important role in preventing and responding to crimes against women, including healthcare, social welfare, education, and criminal justice. Here, we focus on the role of criminal justice agencies, with a particular emphasis on the role of the police. There is significant variation globally in the police response to crimes against women. Many valid concerns have been raised about how police respond to violence against women in developed countries (Hoyle and Sanders 2000; Maier 2008; Stanko 2007). However, the police response to violence against women in many developing nations is often much worse (Heise et al. 1994; Haugen and Boutros 2014; Walsh 2008; Walsh and Menjívar 2016). Police sometimes simply fail to take crimes against women seriously, usually due to incompetence, corruption, or cultural orientations that devalue women. In more serious instances, as Haugen and Boutros (2014, p. 88) note, police in the developing world not only fail to protect women but are also "a force of predatory sexual assault against women and girls in the community".

The police in India are often criticized for not responding effectively to the problem of crimes against women. The most frequent criticism is that due to the patriarchal culture in India, police (most of whom are male) do not take female victims seriously. For instance, Fontes and McCloskey (2011, p. 158) note that brides in rural India are matched with a spouse by their parents "and typically have no real police protection from violence or recourse to divorce". Women often do not report their victimization to the police due 
to social stigma, lack of trust in police, and fear of retaliation by the offender or others (Mukherjee et al. 2001). When women do attempt to report their victimization, the police often refuse to act (Singh 2016). As noted by Prasad (1999, p. 503), Indian police lack the appropriate training and sensitivity to crimes against women, thus rendering them "an obstacle to rather than an agent of state protection". Moreover, police officers in India are sometimes accused of sexually assaulting women, particularly sex workers (Chettiar 2015; Erausquin et al. 2011). For these reasons, many scholars suggest that Indian police agencies need to hire more women (e.g., Tripathi 2020). Moreover, some Indian police agencies have established police stations staffed entirely by women. However, research on their effectiveness is mixed (Amaral et al. 2021; Jassal 2020). Both of these reforms are intended to improve the responsiveness of Indian police agencies to the needs of women, particularly female crime victims.

\subsection{Performance Management}

All organizations-whether public, private, or nonprofit-provide some type of product or service (or both) to external constituents. One of the fundamental questions that arises across different types of organizations is how well they perform in providing these products and services. To answer such questions, organizations typically rely on performance measures. Yet, performance measures alone are not very useful in the absence of managerial practices that use those measures to improve performance (Den Hartog et al. 2004; Johnston and Pongatichat 2008; Kaplan and Norton 2001). The process of managing performance to achieve certain benchmarks is known as performance management (Beer and Ruh 1976). Numerous frameworks or models of performance management have been developed, each based on different theories and assumptions about how to improve organizational effectiveness (Striteska and Spickova 2012). A growing body of research is useful for clarifying the causal sequences through which organizations are able to improve their effectiveness through strategic performance management activities (Walker et al. 2011).

One of the most well-known performance management frameworks is the balanced scorecard (BSC) developed by Kaplan and Norton (1992). The BSC was designed primarily for adoption by firms. It aims to provide managers with information from four perspectives: financial performance, customers, internal processes, and learning and growth. The BSC has helped to usher in a new generation of multidimensional performance measures that focuses on more than just profit. The BSC has had a profound effect on private industry, with thousands of companies adopting this approach as a means of improving their performance (Kaplan 2009). In 1997, the Harvard Business Review listed the BSC among the most influential management ideas of the past 75 years (Sibbet 1997).

With its roots in the private sector, where the ultimate performance measure is profit, the BSC might not seem appropriate for the public sector. However, it has expanded beyond the private sector and is now used "to improve performance management, efficiency and accountability in many countries' public sectors" (Northcott and France 2005, p. 34). Indeed, Kaplan and Norton (2001, p. 98) argue that the BSC can be adapted for use in the public sector by simply "rearranging the scorecard to place customers or constituents at the top of the hierarchy". Research evidence from a variety of settings suggests that the BSC can help to improve performance in governments and public agencies (e.g., Greatbanks and Tapp 2007; Dimitropoulos et al. 2017; Moullin 2017; Srimai et al. 2011).

One of the sectors in which public agencies have begun to use the BSC is policing. For instance, researchers have documented the adoption of the BSC by police agencies in China (Wang et al. 2018), Germany (Masal and Vogel 2016), Portugal (Gomes and Mendes 2013), Scotland (Wisniewski and AlexDickson 2001), Sweden (Andersson and Tengblad 2009; Carmona and Grönlund 2003; Elefalk 2001), and the United Kingdom (Greasley 2004). These studies have demonstrated the effects of the BSC on several key internal and external outcomes, including effectiveness, efficiency, quality of service, and employee job satisfaction. For example, an evaluation in Scotland concluded that the implementation of the BSC provided a police force with a "strategic management framework that can be 
applied across the spectrum of police performance" (Wisniewski and AlexDickson 2001, p. 1065). Another evaluation in Sweden concluded that the BSC was "the most promising avenue for better performance in the police service through the strategic direction and management of police work" (Elefalk 2001, p. 965).

\subsection{Applying Performance Management to Crimes against Women}

Performance management strategies have been one of the key innovations in policing over the past quarter century. They represent a substantial departure from earlier, more traditional approaches to police management. According to Shane (2010, p. 21), the key benefit of a performance management strategy for policing is that "it logically connects what the police intended to achieve with what they actually achieved through empirical measures, better enabling them to account for their performance in a public forum and develop internal capacity to deliver services". Perhaps no performance management strategy has received more attention than Compstat, which was first developed in the New York City Police Department but then spread widely (e.g., Bratton and Malinowski 2008; Jang et al. 2010; Willis et al. 2007). However, research shows that while Compstat rapidly diffused across the landscape of American police agencies, many of the reforms implemented as part of the Compstat movement were more symbolic than substantive. For instance, one study found that frontline officers were "largely oblivious to Compstat, and that it intrudes little, if at all, into their daily work" (Weisburd et al. 2003, p. 449). Other performance management strategies for reducing crime have also been proposed, both for crime in general and for specific types of crime (Hodgkinson et al. 2019; Santos 2013; Stanko 2007).

Although performance management strategies focused specifically on crime control have been used by police agencies to reduce crime, little is known about the effects of more generalized performance management strategies in policing. Performance management frameworks such as the balanced scorecard could improve performance across a wide range of issues and outcomes, but little is known about the extent to which such an approach could influence specific issues such as crimes against women. In this paper, we explore the perspectives of Indian police officials on this question.

\section{Methodology}

This paper examines the association between the perceived importance of the four dimensions of the balanced scorecard model and the expected benefits of the model for improving police response to women by the Uttar Pradesh (UP) police in India. The data used in this paper come from a survey of UP police officials. The first author developed the survey instrument after conducting focus groups and interviews with various stakeholders. These included eight interviews with senior "gazetted" ${ }^{\prime 1}$ police officials, including two retired Directors General of Police (DGPs) and three focus group discussions with female citizens, including some victims of crime. Once we had a draft survey instrument, we shared it with senior police officials to check for content validity and conducted a pilot survey with 30 respondents to test the instrument. We then administered the finalized instrument to a sample of randomly selected gazetted and nongazetted officers. The goal of the instrument was to assess the perspectives of Indian police officials on a variety of issues, including the perceived importance of items and dimensions drawn from the balanced scorecard and the expected benefits of a performance management system for improving police response to crimes against women and the needs of female citizens.

We administered the survey in person to 400 gazetted and nongazetted police officers and received 310 responses, with a final response rate of $77.5 \%$. Table 1 provides demographic information about the respondents. The sample included 265 nongazetted officers $(85.5 \%)$ and 45 gazetted officers $(14.5 \%)$. More than three-quarters of the officers were male $(82.9 \%)$, and more than $90 \%$ had graduated from university or earned a postgraduate degree. 
Table 1. Demographic information for responding police officials.

\begin{tabular}{|c|c|c|c|}
\hline Variable & Category & Number of Respondents & Percentage \\
\hline \multirow{2}{*}{ Designation } & Nongazetted & 265 & $85.5 \%$ \\
\hline & Gazetted & 45 & $14.5 \%$ \\
\hline \multirow{5}{*}{ Qualification } & High School & 0 & $0.0 \%$ \\
\hline & Intermediate & 18 & $5.8 \%$ \\
\hline & University graduate & 146 & $47.1 \%$ \\
\hline & Postgraduate & 143 & $46.1 \%$ \\
\hline & Doctoral & 3 & $1.0 \%$ \\
\hline \multirow{4}{*}{ Age (Years) } & $18-28$ & 99 & $31.9 \%$ \\
\hline & $29-38$ & 60 & $19.4 \%$ \\
\hline & $39-48$ & 90 & $29.0 \%$ \\
\hline & $49+$ & 61 & $19.7 \%$ \\
\hline \multirow{2}{*}{ Gender } & Male & 257 & $82.9 \%$ \\
\hline & Female & 53 & $17.1 \%$ \\
\hline Total & & 310 & $100 \%$ \\
\hline
\end{tabular}

\subsection{Dependent Variable}

The dependent variable in this study was a composite measure of respondents' expectations about how adopting a performance management system such as the BSC would improve the police response to women and the needs of female citizens. We measured expected outcomes using six items that tapped into different elements, such as employee competence and motivation for handling these issues. These items are listed in Appendix A. Scores on each item ranged from one to five, with higher scores indicating greater expected improvement in the police response to women.

\subsection{Independent Variables}

The primary independent variables in this study were composite scales measuring the perceived importance of the four dimensions from the balanced scorecard framework: financial, customer, internal processes, and learning and growth. We measured the perceived importance of each dimension of the BSC using a series of survey questions as indicators of the underlying dimension. All of these survey questions featured Likert-type response options ranging in value from one to five, with higher scores indicating that the respondent views the item as more important for improving police performance. We measured the perceived importance of the financial dimension using eight items that assess respondents' judgments about the importance of financial issues for improving organizational performance. We measured the perceived importance of the customer dimension using eight items that tapped into respondents' judgments about the importance of being community focused. We measured the perceived importance of the internal processes and systems dimension using 10 items that assessed the respondents' judgments about the importance of having appropriate internal processes and systems to carry out the organization's mission. We measured the perceived importance of the learning and growth dimension using nine items that tapped into respondents' judgments about the importance of providing appropriate opportunities for learning and growth among employees. The indicators used for each dimension of the BSC are shown in Appendix B. In addition to the four primary independent variables in the model, we also included controls for age (a four-item ordinal scale with higher scores indicating that the respondent is older), sex ( male $=1$, female $=0$ ), education (postgraduate education $=1$, other $=0)$, and rank (gazetted officer $=1$, nongazetted officer $=0$ ). 


\section{Findings}

Overall, the Indian police officials we interviewed tended to be optimistic about the capacity of a performance management system such as the BSC to improve the police response to women. Across all six items used to measure expected outcomes, a mean of $64.1 \%$ of respondents agreed or strongly agreed that adopting a performance management system could improve the police response to women. On those same questions, $26.2 \%$ neither agreed nor disagreed, and $9.7 \%$ disagreed or strongly disagreed. These patterns suggest that a majority of survey respondents were optimistic that a performance management system could improve the police response to women.

What factors explain variation across respondents in this degree of optimism? To answer this question, we relied on structural equation modeling procedures to test the model outlined in Figure 2. The structural equation model includes both a measurement and a structural component. The measurement component includes five latent variables, each measured using multiple indicators in a confirmatory factor analysis (CFA) framework. ${ }^{2}$ These latent variables are represented as ovals in Figure 2 (to avoid visual complexity, their indicators are not shown). Because the indicators of the latent variables are ordinal, we chose a robust weighted least squares estimator. Simulation research has found that this categorical estimation method works well for models with ordinal indicators (Flora and Curran 2004; Li 2016; Muthén et al. 1997).

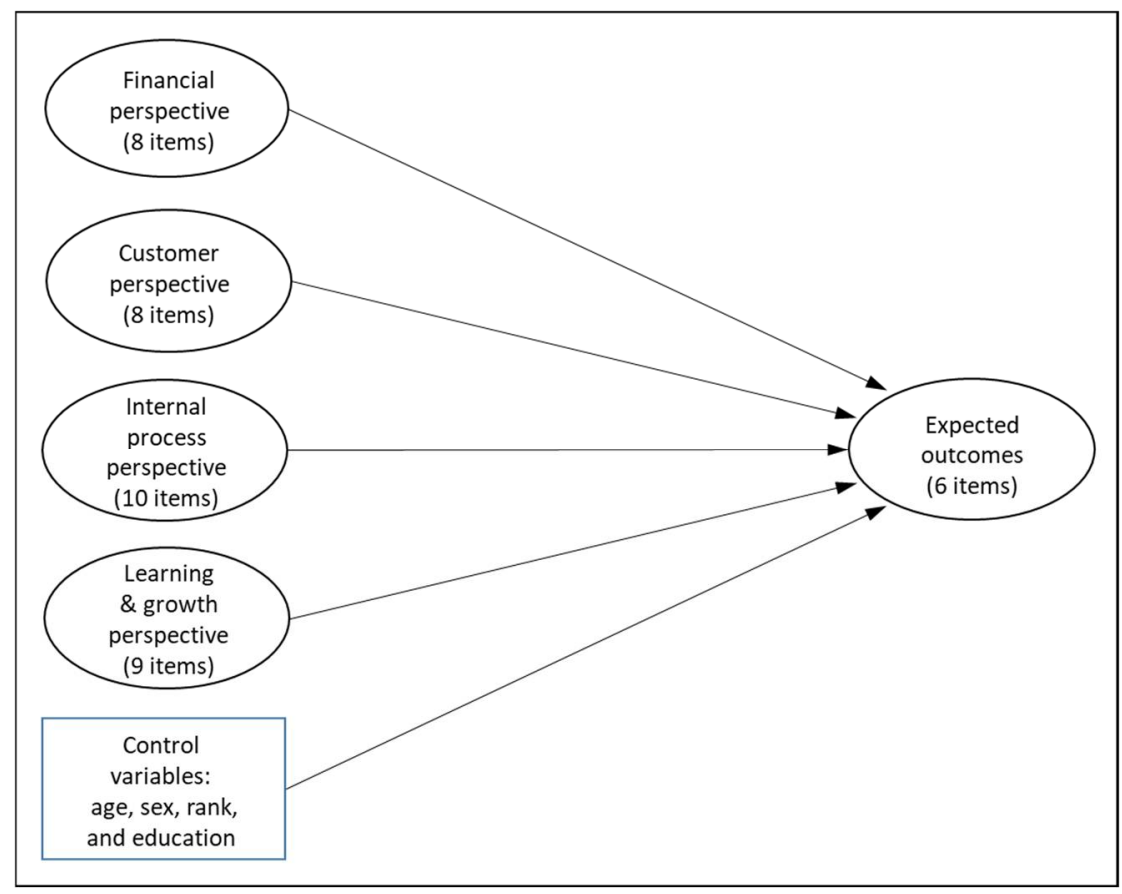

Figure 2. Structural model to be tested. Note: To simplify the visual appearance of the model, we have excluded the indicators of the five latent variables.

We began by testing a measurement model containing only the five latent variables shown in Figure 2: four measuring the perceived importance of dimensions from the BSC framework (financial, customers, internal processes, and learning and growth) and one measuring officers' perceptions of expected outcomes of performance management with regard to the police response to women. Our results revealed that the model fit the data well according to multiple fit indices $\left(\chi^{2}=1225.8, d f=769, p<0.001 ; R M S E A=0.044 ; C F I=\right.$ $0.979 ; T L I=0.978 ; W R M R=0.976) .{ }^{3}$ Across all latent variables in the model, CFA factor loadings ranged from 0.74 to 0.89 , with a mean and median of 0.83 . Several diagnostics have suggested that discriminant validity is not problematic and that the latent variables measure separate, conceptually distinct phenomena. ${ }^{4}$ 
The next step involved testing the full model (including the measurement and structural components) to estimate the effect of the perceived importance of the four dimensions of the BSC and the control variables on officers' expectations about the extent to which performance management would improve the police response to crimes against women. Once again, the model fit the data well according to multiple fit indices $\left(\chi^{2}=1575.0, d f=929\right.$, $p<0.001 ; R M S E A=0.047 ; C F I=0.970 ; T L I=0.968 ; W R M R=1.19)$. Table 2 shows the results from this analysis.

Table 2. Regression results.

\begin{tabular}{lcccc}
\hline \multicolumn{1}{c}{ Independent Variables } & $\boldsymbol{\beta}$ & $\boldsymbol{~ S . E . ~}$ & $\mathbf{t}$ & $\boldsymbol{p}$ \\
\hline Balanced Scorecard Dimensions & & & & \\
\hline Financial perspective & 0.321 & 0.056 & 5.70 & 0.000 \\
\hline Customer perspective & 0.185 & 0.042 & 4.37 & 0.000 \\
\hline Internal process perspective & 0.232 & 0.039 & 6.02 & 0.000 \\
\hline Learning and growth perspective & 0.296 & 0.054 & 5.44 & 0.000 \\
\hline Control Variables & & & & \\
\hline Age & 0.185 & 0.058 & 3.17 & 0.002 \\
\hline Rank & -0.273 & 0.056 & -4.91 & 0.000 \\
\hline Education & 0.149 & 0.058 & 2.56 & 0.011 \\
\hline Male & -0.049 & 0.061 & -0.80 & 0.423 \\
\hline
\end{tabular}

Taken together, the independent variables in the model explained $76.2 \%$ of the variation in expected outcomes, with all four dimensions of the BSC exerting statistically significant effects: financial perspective $(\beta=0.32, p<0.001)$, customer perspective $(\beta=0.19$, $p<0.001)$, internal perspective $(\beta=0.23, p<0.001)$, and learning and growth perspective $(\beta=0.30, p<0.001) .^{5}$ The results suggest that officers' views on all four dimensions of the balanced scorecard influenced their expected outcomes with regard to how police handle crimes against women and the needs of female citizens. The balanced scorecard is a generalized performance management framework. Our findings suggest that each dimension of that framework had a significant, positive association with the extent to which respondents expect that adopting a performance management framework such as the BSC will improve the police response to women. The magnitudes of the standardized regression coefficients were instructive for interpreting the relative effect of each dimension. The coefficients suggest that officers who viewed the financial dimension and the learning and growth dimensions as important for improving performance had higher expectations that adopting a performance management system can improve the police response to women. We explore the relative effects of the four dimensions in more detail in the discussion section.

The results also show that three of the four control variables had significant effects on expected outcomes. Older officers were significantly more likely to expect performance improvements in the police response to women if the BSC were to be adopted $(\beta=0.19$, $p=0.002$ ). More educated officers were also significantly more likely to expect improvements in the police response to women $(\beta=0.15, p=0.011)$. However, gazetted officers were significantly less likely to expect such improvements $(\beta=-0.27, p<0.001)$, an important finding that we explore in more detail in the next section. Finally, the sex of the officer did not have a significant effect on expected outcomes $(\beta=-0.05, p=0.423)$.

\section{Discussion}

The results of our analysis show that officers' judgments about the perceived importance of all four dimensions of the BSC had significant positive effects on the extent to which they anticipate improvements in the police response to women. The financial dimension had the largest impact on expectations about the police meeting women's needs. 
The financial perspective means something different in public sector organizations than it does in the private sector, where financial measures tend to focus on maximizing profit margins and shareholder value. In the public sector, the financial perspective is based on the recognition that "an organisation simply cannot realise its vision and mission if it does not have an adequate financial structure" (Chen et al. 2006, p. 195). Our findings show that those officials who perceive that police performance would improve with financial investments, such as better infrastructure, higher salary and benefits, and performance-based incentives, were significantly more likely to expect improvements in the police response to women. Implicit in this finding is that police officials may view financial constraints as the most important factor (among those examined here) inhibiting their ability to respond effectively to crimes against women. This is not surprising in a nation in which police are chronically understaffed (Kumar 2017).

The dimension with the next largest impact was the learning and growth perspective. Within the BSC framework, learning and growth are viewed as intangible assets that are vital for enacting the organization's overall strategy. This dimension stresses the importance of having an appropriate mix of human capital, information capital, and organizational capital that must be aligned properly with the organization's overall strategy to improve its performance (Kaplan and Norton 1992, 2004). An organization's growth and ability is achieved in large part through its employees (Thompson and Mathys 2008). An organization should have a supportive internal climate that values and facilitates continuous learning for employees to ensure that they can meet the many strategic challenges they face (Garvin et al. 2008).

In police organizations, the learning and growth perspective is especially important to ensure that officers are properly trained and have the appropriate skills. Our findings revealed that those respondents who viewed the learning and growth perspective as important were significantly more likely to expect performance improvements in the police response to women. This finding suggests that police officials may view learning and growth issues as inhibiting their ability to respond effectively to crimes against women. Previous research on police in India has found that training is associated with greater job involvement, job satisfaction, and organizational commitment (Lambert et al. 2015).

The dimension with the third largest impact was the internal process perspective, which focuses on the extent to which work is done efficiently and effectively and in a manner that is consistent with the organization's overall strategy. This dimension stresses the importance of having appropriate processes related to recruiting, hiring, training, and performance management that are properly aligned and coordinated. These processes enable organizations to monitor their progress toward meeting their strategic goals and adjust as needed to optimize performance. Our findings demonstrated that those respondents who viewed the internal process perspective as important were significantly more likely to expect a performance management system to improve the police response to women. Research on police in India has found robust evidence that altering internal organizational processes can improve police performance (Banerjee et al. 2021).

The dimension with the weakest impact was the customer perspective, which is often viewed as the most important of the four BSC dimensions in public sector organizations (Kaplan and Norton 2001). Research suggests that identifying who constitutes the "customer" in a public organization is sometimes not very straightforward (Northcott and Taulapapa 2012). These issues are especially challenging in policing, where some people who encounter the police do so involuntarily, such as those who are stopped, searched, or arrested by police (Maguire and Johnson 2010; Sarrico et al. 2013). At the same time, improving relationships between police and communities is central to most of the major strategic reform movements in policing (President's Task Force on 21st Century Policing 2015; Skogan and Frydl 2004). Our findings revealed that those respondents who viewed the customer perspective as important were significantly more likely to expect improvements in the police response to women. However, the customer perspective had the weakest impact of the four BSC dimensions on expected outcomes. Attending carefully 
to the customer perspective may be especially important for improving the police response to crimes against women in India. For example, research on intimate partner violence in India has found that many women are afraid to report their victimization to the police and do not view the police as a helpful resource (Ragavan et al. 2015).

We also included four sociodemographic variables in the multivariate model to control for their effects, not for substantive theoretical reasons. Nonetheless, the effects of these variables reveal some interesting and important patterns. Our findings with regard to the effect of age show that older respondents were more likely to expect improvements in the police response to women than younger respondents. This is an unexpected finding and we do not have a ready explanation for it. Figure 3 shows the findings from a supplementary analysis of the effects of age on expected outcomes with regard to the police response to women. ${ }^{6}$ It shows that expected outcomes were lowest in the youngest age bracket (18-28 years old) and slightly higher in the second youngest age bracket (29-38 years old). They peak in the next age bracket (39-48 years old) and then decline in the oldest age bracket (49+ years old). Thus, the effects of age on expected outcomes were nonlinear. This finding deserves more research, particularly as the youngest officers who constitute the next generation of policing in Uttar Pradesh had the lowest level of optimism that performance management can improve the police response to women.

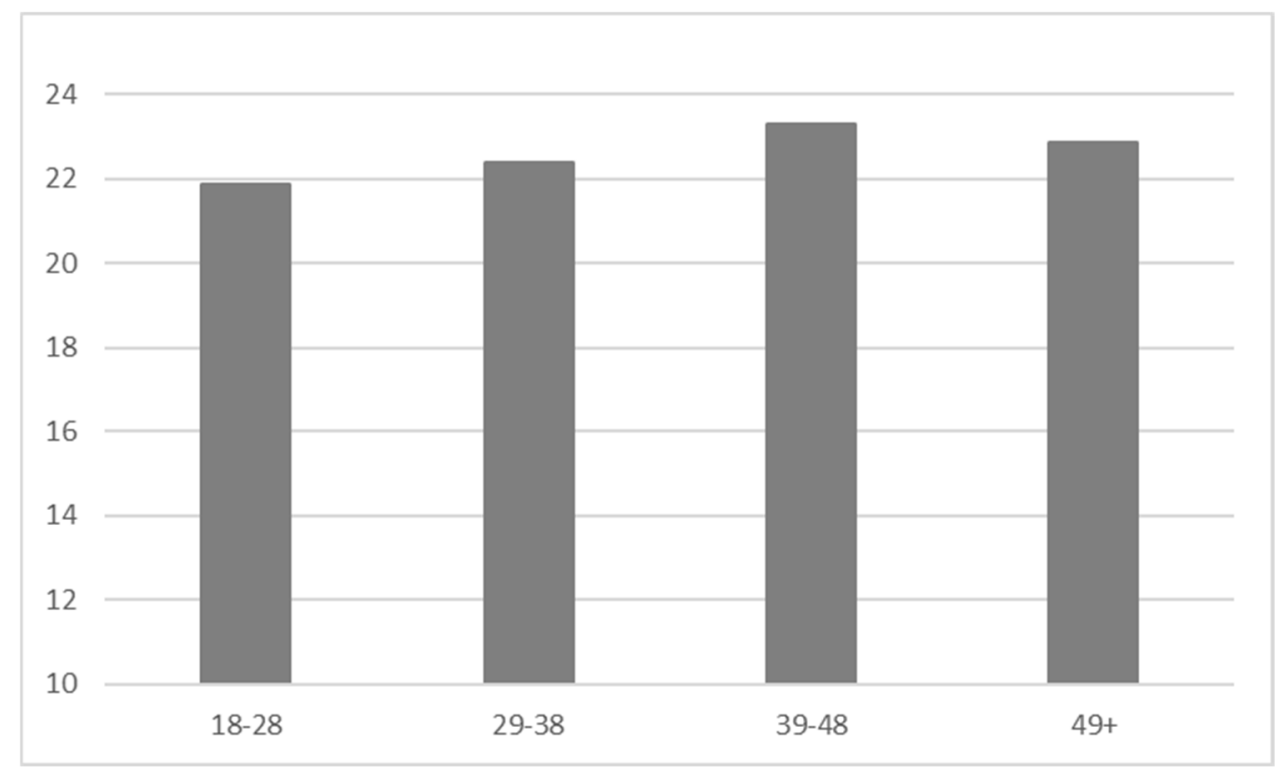

Figure 3. The effects of age on expected outcomes. Note: The four bars represent different age categories (18-28, 29-38, 39-48, and 49+). The height of the bars represents higher expectations about the ability of police to respond appropriately to crimes against women and the needs of female citizens.

Our findings with regard to rank show that gazetted (senior) officers were less optimistic that a performance management system such as the BSC could improve the police response to women than nongazetted (junior) officers. This is a noteworthy finding because it suggests that police leaders with the greatest authority to implement change are the least likely to expect improvements in how police respond to crimes against women and the needs of female citizens. This finding raises important questions about the extent to which gazetted officers may experience a form of organizational cynicism that views change efforts as futile (Dean et al. 1998; Reichers et al. 1997).

The results with regard to education are not surprising. Respondents who were more educated were more likely to view performance management as a viable approach for developing appropriate police responses to women's needs. This finding is consistent with research elsewhere showing that education is associated with more egalitarian attitudes 
toward gender issues (Phinney and Flores 2002; Yoshihama et al. 2014). Finally, male and female respondents were equally likely to anticipate improvements in police response to women. This interesting finding raises important questions about the extent to which female police officials are optimistic about their ability to enact changes in policing. The patterns we have highlighted with regard to the effects of sociodemographic factors represent worthy topics for future research seeking to illuminate the facilitators and obstacles to change in how police respond to the needs of women in India.

India is a patriarchal society in which "women's subordination status and inequalities are reflected in almost every sphere" (Chowdhury and Patnaik 2010, p. 455). In spite of these challenges, there are signs of progress. Reductions in the gender gap in India are now evident with regard to political empowerment, educational attainment, literacy, and life expectancy (Ghosh 2018). The nation has also provided opportunities to women in many fields. These include improved job prospects in the private and public sectors but also in developing entrepreneurial and leadership skills (Dana 2007). India has expanded the opportunities for women, but the nation also presents numerous obstacles to full equality. Women in India continue to struggle with disrespect, discrimination, criminal victimization, and other forms of inequality (Dana 2014; Hebert et al. 2020; Mogford 2011; Verma et al. 2017). These serious social problems limit the ability of women to prosper and to achieve their full potential. Societies that tolerate the criminal victimization of women and police institutions that fail to respond robustly and compassionately to this issue are reinforcing profound social inequalities and hindering human development (Carrillo 1993; Haugen and Boutros 2014).

For these and many other reasons, improving the police response to crimes against women and the needs of women more generally is essential. In this paper, we examined the association between perceptual measures derived from the balanced scorecard, a performance management framework that has been adopted widely in both the private and public sectors, and police officials' expectations about whether such a framework could help police improve their response to female citizens. The findings revealed that the perceived importance of all four dimensions of the balanced scorecard had significant positive effects on expected outcomes. The findings reported here are useful for thinking about how to improve the police response to crimes against women in India and to meet the needs of female citizens in India more generally. Police institutions in India are clearly not meeting the needs of female citizens. Learning how to develop more responsive police institutions that meet the needs of female citizens is essential. Much more research is needed to achieve a deeper understanding of what women need from the police globally and what changes police institutions can put in place to address those needs in a competent, compassionate, and professional manner.

Author Contributions: Conceptualization, M.K.; data collection, M.K.; analysis, E.R.M.; writing, M.K. and E.R.M. All authors have read and agreed to the published version of the manuscript.

Funding: This research received no external funding.

Informed Consent Statement: Informed consent was obtained from all subjects involved in the study.

Data Availability Statement: Not applicable.

Conflicts of Interest: The authors declare no conflict of interest.

\section{Appendix A. Expected Outcomes}

Question: To what extent do you agree that adopting a new performance management system like the balanced scorecard would result in the outcomes listed below?

CAW1. Better response of police officers to women;

CAW2. Competence in the workforce to handle crimes against women;

CAW3. Motivated workforce to address issues of crimes against women;

CAW4. Enhance efficiency and output with regard to crimes against women; 
CAW5. Decreased rate of crimes against women;

CAW6. Satisfaction with police among female citizens.

\section{Appendix B. Indicators of Four Balanced Scorecard Dimensions}

Question: How important is each item below for enhancing the performance of police officials in the organisation?

Financial Perspective

F1. Budget allocated by government as per department requirement;

F2. Financial resources given by the government accelerates efficiency;

F3. Resources used fairly to address the needs of department;

F4. Salary \& compensation offered to the officers as per the nature of job;

F5. Modern infrastructural amenities given to workforce;

F6. Functional resources given to do the job;

F7. Changes in mode of expenditure;

F8. Financial gains to the department through grants.

Customer Perspective

$\overline{\mathrm{C}}$. Patrolling, vigilance, sources, and community policing add value;

C2. Reducing crime, victimization and fear, and enhancing security would improve citizens' confidence;

C3. Citizens' satisfaction is of utmost priority;

C4. Resolving conflict between public and police;

C5. Public support during investigations;

C6. Using pressure, force, and authority fairly on citizens;

C7. Exhibiting good behaviour/fair attitude and treating complainant well;

C8. Proactive approach rather than reactive approach.

Internal Process \& Systems Perspective

IP1. Performance appraisal mechanisms in the department;

IP2. Strict adherence to follow protocol;

IP3. Responsibilities with authority should be delegated;

IP4. Decision making power and span of control;

IP5. Codified list of duties;

IP6. Policies related to systematic and justified working hours/leave rules/shifts;

IP7. Flow of communication in the department;

IP8. Superior-subordinate relationships;

IP9. Working environment, culture, and conditions affect performance;

IP10. Establishing performance standards.

Learning \& Growth Perspective

LG1. Focus on latest skills and technology;

LG2. Training for the officers;

LG3. Annual calendars for refresher courses;

LG4. Specific trainings for women-related issues;

LG5. Opportunities for growth and promotion;

LG6. Better communication within the department;

LG7. Strategic awareness and motivation;

LG8. Restructuring methods to create competent, trained and motivated workforce;

LG9. Creating awareness for performance standards.

\section{Notes}

In the Indian Police Service, a gazetted officer is a manager or executive with a rank of Inspector or higher. Those with a rank of Assistant Inspector or below are nongazetted officers.

2 We treated the ordinal survey responses used to measure these latent variables as crudely categorized approximations of underlying continuous random variables. Although the indicators were categorical, the latent variables were assumed continuous. Many of the procedures used in conventional confirmatory factor analysis with continuous indicators need to be adapted for use with ordinal indicators (Brown 2015). 
3 The model fit the data well according to four of the five fit statistics (CFI, TLI, RMSEA, and WRMR) but not $\chi^{2}$. Though researchers routinely report $\chi^{2}$ in structural equation models, its diagnostic value as a measure of fit has been questioned because it is often too strict (Bowen and Guo 2012).

4 The correlations between factors ranged from 0.41 to 0.78 , with a mean of 0.57 and median of 0.56 . Correlations of less than 0.8 between factors typically signify that discriminant validity is not problematic (Brown 2015). We used two additional methods to test for discriminant validity. The first is that the $95 \%$ confidence interval of the zero-order correlations between factors cannot include 1 (Bagozzi et al. 1991). The second is that each factor must account for more variance in its indicators than it shares with other factors within the model (Fornell and Larcker 1981). All tests revealed that discriminant validity was not problematic within the measurement model tested here.

5 As part of our model diagnostics, we computed variance inflation factors (VIFs) for all independent variables in the model. VIF values ranged from 1.1 to 2.6 , with a mean of 1.5 and a median of 1.3. These values fall well below the commonly used threshold of 10 for inferring a problem with multicollinearity (Marquardt 1970). Therefore, we conclude that multicollinearity was not an issue in this study.

6 We computed an additive index based on the six indicators of expected outcomes with regard to the police response to women. Each indicator ranged from one to five, with higher scores indicating higher expected performance outcomes. The overall index had a possible range of $6-30$. Figure 3 shows the mean scores on the index for the four age categories $(18-28,29-38,39-48$, and $49+)$. The height of the bars in Figure 3 represents expected outcomes. Respondents in the 39-48 age bracket had the highest scores on the expected outcomes index, suggesting that they were the most optimistic about the ability of police to improve their response to crimes against women and the needs of female citizens.

\section{References}

Ahmad, Jaleel, M. E. Khan, Arupendra Mozumdar, and Deepthi S Varma. 2016. Gender-based violence in rural Uttar Pradesh, India: Prevalence and association with reproductive health behaviors. Journal of Interpersonal Violence 31: 3111-28. [CrossRef] [PubMed]

Amaral, Sofia, Sonia Bhalotra, and Nishith Prakash. 2021. Gender, Crime and Punishment: Evidence from Women Police Stations in India. Available online: https: / / ssrn.com/abstract=3827615 (accessed on 4 January 2021).

Andersson, Thomas, and Stefan Tengblad. 2009. When complexity meets culture: New public management and the Swedish police. Qualitative Research in Accounting \& Management 6: 41-56.

Bagozzi, Richard P., Youjae Yi, and Lynn W. Phillips. 1991. Assessing construct validity in organizational research. Administrative Science Quarterly 36: 421-58. [CrossRef]

Banerjee, Abhijit, Raghabendra Chattopadhyay, Esther Duflo, Daniel Keniston, and Nina Singh. 2021. Improving police performance in Rajasthan, India: Experimental evidence on incentives, managerial autonomy, and training. American Economic Journal: Economic Policy 13: 36-66. [CrossRef]

Beer, Micheal, and Roberb Ruh. 1976. Employee growth through performance management. Harvard Business Review 54: 59-66.

Bowen, Natasha K., and Shenyang Guo. 2012. Structural Equation Modeling. New York: Oxford University Press.

Bratton, William J., and Sean Malinowski. 2008. Police performance management in practice: Taking COMPSTAT to the next level. Policing: A Journal of Policy and Practice 2: 259-65. [CrossRef]

Brown, Timothy A. 2015. Confirmatory Factor Analysis for Applied Research, 2nd ed. New York: The Guilford Press.

Carmona, Salvador, and Anders Grönlund. 2003. Measures vs. actions: The balanced scorecard in Swedish Law Enforcement. International Journal of Operations \& Production Management 23: 1475-96.

Carrillo, Roxanna. 1993. Violence against women: An obstacle to development. In Women's Lives and Public Policy: The International Experience. Edited by Meredeth Turshen and Briavel Holcomb. Westport: Greenwood Press, pp. 99-114.

Chen, Shun-Hsing, Ching-Chow Yang, and Jiun-Yan Shiau. 2006. The application of balanced scorecard in the performance evaluation of higher education. The TQM Magazine 18: 190-205. [CrossRef]

Chettiar, Anitha. 2015. Problems faced by hijras (male to female transgenders) in Mumbai with reference to their health and harassment by the police. International Journal of Social Science and Humanity 5: 752-59. [CrossRef]

Chowdhury, Aparajita, and Manoj Manjari Patnaik. 2010. Empowering boys and men to achieve gender equality in India. Journal of Developing Societies 26: 455-71. [CrossRef]

Crowell, Nancy A., and Ann W. Burgess, eds. 1996. Understanding Violence against Women. Washington, DC: National Research Council.

Dana, Léo-Paul. 2007. Asian Models of Entrepreneurship_From the Indian Union and the Kingdom of Nepal to the Japanese Archipelago: Context, Policy and Practice. Singapore: World Scientific.

Dana, Léo-Paul. 2014. Asian Models of Entrepreneurship_From the Indian Union and Nepal to the Japanese Archipelago: Context, Policy and Practice, 2nd ed. Singapore: World Scientific.

Dean, James W., Jr., Pamela Brandes, and Ravi Dharwadkar. 1998. Organizational cynicism. The Academy of Management Review 23: 341-52. [CrossRef]

DeKeseredy, Walter S., and Martin D. Schwartz. 2011. Theoretical and definitional issues in violence against women. In Sourcebook on Violence against Women, 2nd ed. Edited by Claire M. Renzetti, Jeffrey L. Edleson and Raquel Kennedy Bergen. Los Angeles: Sage, pp. 3-20. 
Den Hartog, Deanne N., Paul Boselie, and Jaap Paauwe. 2004. Performance management: A model and research agenda. Applied Psychology 53: 556-69. [CrossRef]

Dimitropoulos, Panagiotis, Ioannis Kosmas, and Ioannis Douvis. 2017. Implementing the balanced scorecard in a local government sport organization. International Journal of Productivity and Performance Management 66: 362-79. [CrossRef]

Elefalk, Kjell. 2001. The balanced scorecard of the Swedish Police Service: 7000 officers in total quality management project. Total Quality Management 12: 958-66. [CrossRef]

Erausquin, Jennifer Toller, Elizabeth Reed, and Kim M. Blankenship. 2011. Police-related experiences and HIV risk among female sex workers in Andhra Pradesh, India. Journal of Infectious Diseases 204: S1223-S1228. [CrossRef]

Flora, David B., and Patrick J. Curran. 2004. An empirical evaluation of alternative methods of estimation for confirmatory factor analysis with ordinal data. Psychological Methods 9: 466-91. [CrossRef]

Fontes, Lisa Aronson, and Kathy A. McCloskey. 2011. Cultural issues in violence against women. In Sourcebook on Violence against Women, 2nd ed. Edited by Claire M. Renzetti, Jeffrey L. Edleson and Raquel Kennedy Bergen. Los Angeles: Sage, pp. 151-68.

Fornell, Claes, and David F. Larcker. 1981. Evaluating structural equation models with unobservable variables and measurement error. Journal of Marketing Research 18: 39-50. [CrossRef]

Gallagher, Catherine, Stephen D. Mastrofski, Edward Maguire, and Michael D. Reisig. 2001. The Public Image of the Police. Alexandria: International Association of Chiefs of Police.

Garvin, David A., Amy C. Edmondson, and Francesca Gino. 2008. Is yours a learning organization? Harvard Business Review 86: 109-18.

Ghosh, Madhusudan. 2018. Gender equality, growth and human development in India. Journal of Poverty Alleviation and International Development 9: 68-87.

Gomes, Patrícia, and Silvia M. Mendes. 2013. Performance measurement and management in Portuguese law enforcement. Public Money \& Management 33: 33-38.

Greasley, Andrew. 2004. Process improvement within a HR division at a UK police force. International Journal of Operations $\mathcal{E}$ Production Management 24: 230-40.

Greatbanks, Richard, and David Tapp. 2007. The impact of balanced scorecards in a public sector environment: Empirical evidence from Dunedin City Council, New Zealand. International Journal of Operations \& Production Management 27: 846-73.

Haugen, Gary A., and Victor Boutros. 2014. The Locust Effect: Why the End of Poverty Requires the End of Violence. New York: Oxford University Press.

Hebert, Luciana E., Suchi Bansal, Soo Young Lee, Shirley Yan, Motolani Akinola, Márquez Rhyne, Alicia Menendez, and Melissa Gilliam. 2020. Understanding young women's experiences of gender inequality in Lucknow, Uttar Pradesh through story circles. International Journal of Adolescence and Youth 25: 1-11. [CrossRef] [PubMed]

Heise, Lori L., Alanagh Raikes, Charlotte H. Watts, and Anthony B. Zwi. 1994. Violence against women: A neglected public health issue in less developed countries. Social Science \& Medicine 39: 1165-79.

Himabindu, B. L., Radhika Arora, and Nuggehalli Srinivas Prashanth. 2014. Whose problem is it anyway? Crimes against women in India. Global Health Action 7: 1-6. [CrossRef]

Hodgkinson, Tarah, Tullio Caputo, and Michael L. McIntyre. 2019. Beyond crime rates and community surveys: A new approach to police accountability and performance measurement. Crime Science 8: 1-7. [CrossRef]

Hoyle, Carolyn, and Andrew Sanders. 2000. Police response to domestic violence. The British Journal of Criminology 40: 14-36. [CrossRef]

Jang, Hyunseok, Larry T. Hoover, and Hee-Jong Joo. 2010. An evaluation of Compstat's effect on crime: The Fort Worth experience. Police Quarterly 13: 387-412. [CrossRef]

Jassal, Nirvikar. 2020. Gender, law enforcement, and access to justice: Evidence from all-women police stations in India. American Political Science Review 114: 1035-54. [CrossRef]

Johnston, Robert, and Panupak Pongatichat. 2008. Managing the tension between performance measurement and strategy: Coping strategies. International Journal of Operations \& Production Management 28: 941-67.

Kaplan, Robert. 2009. Conceptual foundations of the balanced scorecard. In Handbook of Management Accounting Research. Edited by Christopher S. Chapman, Anthony G. Hopwood and Michael D. Shields. Oxford: Elsevier, vol. 3, pp. $1253-69$.

Kaplan, Robert S., and David P. Norton. 1992. The balanced scorecard: Measures that drive performance. Harvard Business Review 70: 71-79. [PubMed]

Kaplan, Robert S., and David P. Norton. 2001. Transforming the balanced scorecard from performance measurement to strategic management: Part 1. Accounting Horizons 15: 87-104. [CrossRef]

Kaplan, Robert S., and David P. Norton. 2004. The strategy map: Guide to aligning intangible assets. Strategy and Leadership 32: 10-17. [CrossRef]

Kumar, T. K. Vinod. 2017. Factors impacting job satisfaction among police personnel in India: A multidimensional analysis. International Criminal Justice Review 27: 126-48. [CrossRef]

Lambert, Eric G., Hanif Qureshi, Nancy L. Hogan, Charles Klahm, Brad Smith, and James Frank. 2015. The association of job variables with job involvement, job satisfaction, and organizational commitment among Indian police officers. International Criminal Justice Review 25: 194-213. [CrossRef]

Langworthy, Robert H. 1986. The Structure of Police Organizations. New York: Praeger.

Li, Cheng-Hsien. 2016. Confirmatory factor analysis with ordinal data: Comparing robust maximum likelihood and diagonally weighted least squares. Behavior Research Methods 48: 936-49. [CrossRef] [PubMed] 
Maddox, Lucy, Deborah Lee, and Chris Barker. 2011. Police empathy and victim PTSD as potential factors in rape case attrition. Journal of Police and Criminal Psychology 26: 112-17. [CrossRef]

Maguire, Edward R. 2003. Organizational Structure in American Police Agencies: Context, Complexity, and Control. Albany: State University of New York Press.

Maguire, Edward R. 2004. Police Departments as Learning Laboratories; Washington, DC: The National Police Foundation. Available online: http:/ / www.policefoundation.org/pdf/Ideas-Maguire.pdf (accessed on 1 October 2021).

Maguire, Edward R. 2005. Measuring the performance of law enforcement agencies. Law Enforcement Executive forum 5: 1-31.

Maguire, Edward R., and Devon Johnson. 2010. Measuring public perception of police. Policing: An International Journal of Police Strategies and Management 33: 703-30. [CrossRef]

Maier, Shana L. 2008. "I have heard horrible stories...": Rape victim advocates' perceptions of the revictimization of rape victims by the police and medical system. Violence against Women 14: 786-808. [CrossRef]

Mangoli, R. N., and N. Ganapati Tarase. 2009. Crime against women: A statistical review. International Journal of Criminology and Sociological Theory 2: 292-302.

Marquardt, Donald W. 1970. Generalized inverses, ridge regression, biased linear estimation, and nonlinear estimation. Technometrics 12: 591-612. [CrossRef]

Masal, Doris, and Rick Vogel. 2016. Leadership, use of performance information, and job Satisfaction: Evidence from police services International Public Management Journal 19: 208-34. [CrossRef]

McFarlane, Judith, Lene Symes, Brenda K. Binder, J. Maddoux, and Rene Paulson. 2014. Maternal-child dyads of functioning: The intergenerational impact of violence against women on children. Maternal and Child Health Journal 18: 2236-43. [CrossRef]

Michau, Lori, Jessica Horn, Amy Bank, Mallika Dutt, and Cathy Zimmerman. 2015. Prevention of violence against women and girls: Lessons from practice. The Lancet 385: 1672-84. [CrossRef]

Mogford, Elizabeth. 2011. When status hurts: Dimensions of women's status and domestic abuse in rural northern India. Violence against Women 17: 835-57. [CrossRef] [PubMed]

Mohan, Deepanshu, and Niharika Yadav. 2019. No State for Women? Why Crimes against Women Are Rising in UP. The Wire. Available online: https://thewire.in/women/crimes-against-women-violence-uttar-pradesh-unnao (accessed on 4 January 2021).

Moore, Mark Harrison. 2002. Recognizing Value in Policing: The Challenge of Measuring Police Performance. Washington, DC: Police Executive Research Forum.

Moore, Mark Harrison. 2003. The "Bottom Line" of Policing: What Citizens Should Value (and Measure!) in Police Performance. Washington, DC: Police Executive Research Forum.

Moullin, Max. 2017. Improving and evaluating performance with the public sector scorecard. International Journal of Productivity and Performance Management 66: 442-58. [CrossRef]

Mukherjee, Chandan, Preet Rustagi, and N. Krishnaji. 2001. Crimes against women in India: Analysis of official statistics. Economic and Political Weekly 36: 4070-80.

Muthén, Bengt O., Stephen H. C. du Toit, and Damir Spisic. 1997. Robust Inference Using Weighted Least Squares and Quadratic Estimating Equations in Latent Variable Modeling with Categorical and Continuous Outcomes. Available online: http://gseis. ucla.edu/faculty/muthen/articles/Article_075.pdf (accessed on 1 October 2021).

National Crime Records Bureau. 2019. Crime in India 2018; New Delhi: Ministry of Home Affairs.

Neyroud, Peter. 2008. Past, present and future performance: Lessons and prospects for the measurement of police performance. Policing 2: 340-48. [CrossRef]

Northcott, Deryl, and Necia France. 2005. The balanced scorecard in New Zealand health sector performance management: Dissemination to diffusion. Australian Accounting Review 15: 34-46. [CrossRef]

Northcott, Deryl, and Tuivaiti Ma'amora Taulapapa. 2012. Using the balanced scorecard to manage performance in public sector organizations: Issues and challenges. International Journal of Public Sector Management 25: 166-91. [CrossRef]

Phinney, Jean S., and Juana Flores. 2002. "Unpackaging" acculturation: Aspects of acculturation as predictors of traditional sex role attitudes. Journal of Cross-Cultural Psychology 33: 320-31. [CrossRef]

Pico-Alfonso, Maria A., M. Isabel Garcia-Linares, Nuria Celda-Navarro, Concepción Blasco-Ros, Enrique Echeburúa, and Manuela Martinez. 2006. The impact of physical, psychological, and sexual intimate male partner violence on women's mental health: Depressive symptoms, posttraumatic stress disorder, state anxiety, and suicide. Journal of Women's Health 15: 599-611. [CrossRef] [PubMed]

Prasad, Shally. 1999. Medicolegal response to violence against women in India. Violence against Women 5: 478-506. [CrossRef] [PubMed]

President's Task Force on 21st Century Policing. 2015. Final Report of the President's Task Force on 21st Century Policing. Washington, DC: Office of Community Oriented Policing Services.

Ragavan, Maya, Kirti Iyengar, and Rebecca Wurtz. 2015. Perceptions of options available for victims of physical intimate partner violence in northern India. Violence against Women 21: 652-75. [CrossRef]

Reichers, Arnon, John Wanous, and James Austin. 1997. Understanding and managing cynicism about organizational change. The Academy of Management Executive 11: 48-59. [CrossRef]

Rollings, Kiah, and Natalie Taylor. 2008. Measuring police performance in domestic and family violence. Trends $\mathcal{E}$ Issues in Crime and Criminal Justice 367: 1-6. 
Santos, Rachel B. 2013. Implementation of a police organizational model for crime reduction. Policing: An International Journal 36: 295-311. [CrossRef]

Sarrico, Claudia S., Luís Miguel D. F. Ferreira, and Luís Filipe Cardoso Silva. 2013. POLQUAL-Measuring service quality in police traffic services. International Journal of Quality and Service Sciences 5: 275-89. [CrossRef]

Schwerdtfeger, K. L., and B. S. N. Goff. 2007. Intergenerational transmission of trauma: Exploring mother-infant prenatal attachment. Journal of Traumatic Stress 20: 39-51. [CrossRef]

Shane, Jon M. 2010. Performance management in police agencies: A conceptual framework. Policing: An International Journal of Police Strategies and Management 33: 6-29. [CrossRef]

Sherman, Lawrence W., Janell D. Schmidt, and Dennis P. Rogan. 1992. Policing Domestic Violence: Experiments and Dilemmas. New York: Free Press.

Sibbet, David. 1997. 75 years of management ideas and practice 1922-1997. Harvard Business Review 75: 2-12.

Silverman, Jay G., Sabrina C. Boyce, Nabamallika Dehingia, Namratha Rao, Dharmoo Chandurkar, Priya Nanda, Katherine Hay, Yamini Atmavilas, Niranjan Saggurti, and Anita Raj. 2019. Reproductive coercion in Uttar Pradesh, India: Prevalence and associations with partner violence and reproductive health. SSM Population Health 9: 1-7. [CrossRef]

Simons, Margaret, and Jenny Morgan. 2018. Changing media coverage of violence against women. Journalism Studies 19: 1202-17. [CrossRef]

Singh, Sanjay K. 2016. Heinous crimes against women in India. The Journal of Social, Political, and Economic Studies 41: 51-73.

Skogan, Wesley, and Kathleen Frydl. 2004. Fairness and Effectiveness in Policing: The Evidence. Washington, DC: Office of Community Oriented Policing Services.

Sparrow, Malcolm K. 2015. Measuring performance in a modern police organisation. In New Perspectives in Policing Bulletin. Washington, DC: U.S. Department of Justice, National Institute of Justice.

Spohn, Cassia, and Katharine Tellis. 2015. Policing and prosecuting sexual assault: Assessing the pathways to justice. In Critical Issues in Violence against Women: International Perspectives and Promising Strategies. Edited by Holly Johnson, Bonnie S. Fisher and Veronique Jaquier. New York: Routledge, pp. 93-103.

Srimai, Suwit, Nitirath Damsaman, and Sirilak Bangchokdee. 2011. Performance measurement, organizational learning and strategic alignment: An exploratory study in Thai public sector. Measuring Business Excellence 15: 57-69. [CrossRef]

Stanko, Betsy A. 2007. From academia to policy making: Changing police responses to violence against women. Theoretical Criminology 11: 209-19. [CrossRef]

Stein, Murray B., and Colleen Kennedy. 2001. Major depressive and post-traumatic stress disorder comorbidity in female victims of intimate partner violence. Journal of Affective Disorders 66: 133-38. [CrossRef]

Striteska, Michaela, and Marketa Spickova. 2012. Review and comparison of performance measurement systems. Journal of Organizational Management Studies 2012: 114900. [CrossRef]

Sudha, S., and Sharon Morrison. 2011. Marital violence and women's reproductive health care in Uttar Pradesh, India. Women's Health Issues 21: 214-21. [CrossRef]

Thompson, K. R., and N. J. Mathys. 2008. The aligned balanced scorecard: An improved tool for building high performance organizations. Organizational Dynamics 37: 378-93. [CrossRef]

Tripathi, Saumya. 2020. Patriarchal beliefs and perceptions towards women among Indian police officers: A study of Uttar Pradesh, India. International Journal of Police Science \& Management 22: 232-41.

United Nations Development Programme. 2018. Gender Inequality Index. Available online: http://hdr.undp.org/en/composite/GII (accessed on 1 October 2021).

Verma, Arvind, Hanif Qureshi, and Jee Yearn Kim. 2017. Exploring the trend of violence against women in India. International Journal of Comparative and Applied Criminal Justice 41: 3-18. [CrossRef]

Walker, Richard M., Fariborz Damanpour, and Carlos A. Devece. 2011. Management innovation and organizational performance: The mediating effect of performance management. Journal of Public Administration Research and Theory 21: 367-86. [CrossRef]

Walsh, Shannon Drysdale. 2008. Engendering justice: Constructing institutions to address violence against women. Studies in Social Justice 2: 48-66. [CrossRef]

Walsh, Shannon Drysdale, and Cecilia Menjívar. 2016. Impunity and multisided violence in the lives of Latin American women: El Salvador in comparative perspective. Current Sociology 64: 586-602. [CrossRef]

Wang, Shiyao, Jianguang Zhang, and Yunjia Sun. 2018. Armed police financial performance evaluation method design: A research perspective based on balanced scorecard. Advances in Social Science, Education, and Humanities Research 233: 987-92.

Weisburd, David L., Stephen D. Mastrofski, Ann Marie McNally, Rosann Greenspan, and James J. Willis. 2003. Reforming to preserve: COMPSTAT and strategic problem solving in American policing. Criminology and Public Policy 23: 421-56. [CrossRef]

Willis, James J., Stephen D. Mastrofski, and David Weisburd. 2007. Making sense of COMPSTAT: A theory-based analysis of organizational change in three police departments. Law \& Society Review 41: 147-88.

Wisniewski, Milk, and AlexDickson. 2001. Measuring performance in Dumfries and Galloway Constabulary with the balanced scorecard. Journal of the Operational Research Society 52: 1057-66. [CrossRef]

World Health Organization. 2013. Global and Regional Estimates of Violence against Women: Prevalence and Health Effects of Intimate Partner Violence and Non-Partner Sexual Violence. Geneva: World Health Organization. 
Yoshihama, Mieko, Juliane Blazevski, and Deborah Bybee. 2014. Enculturation and attitudes toward intimate partner violence and gender roles in an Asian Indian population: Implications for community-based prevention. American Journal of Community Psychology 53: 432-32. [CrossRef] [PubMed]

Zoellner, Lori A., Melanie L. Goodwin, and Edna B. Foa. 2000. PTSD severity and health perceptions in female victims of sexual assault. Journal of Traumatic Stress 13: 635-49. [CrossRef] [PubMed] 